\title{
Studies on effects of graded levels of zinc and Trichoderma viride, Pseudomonas strita on yield and quality attributing characters in tomato (Lycopersicon esculentum L.)
}

\author{
H. R. Galande, A.M. Bhosale*, S.J. Syed ${ }^{1}$ and Basir Ahmad Ahmadi \\ Department of Horticulture, College of Agriculture, Vasantrao Naik Marathwada Krishi Vidyapeeth, Parbhani, \\ (M.S.) India (Email: ambhosale78@gmail.com)
}

\begin{abstract}
The present investigation "Studies on effects of graded levels of zinc and Trichoderma viride, Pseudomonas strita on yield and quality attributing characters in tomato (Lycopersicon esculentum L.)". The experiment was laid out in Factorial RBD with two factor i.e. factor first is zinc solubilizers and factor second is levels of zinc, it has twelve treatments replicated three times. Trichoderma viride and Pseudomonas strita are used as source zinc solubilizers along with different levels of zinc. The experiment framed was intended to study the effect of zinc solubilizers and levels of zinc on yield and quality of tomato.The results revealed that effect of zinc solubilizers on yield and quality parameters of tomato indicated that the zinc solubilizer $\mathrm{B}_{2}$ (Trichoderma viride) recorded maximum fruit yield per plant (1458.76 gm), fruit yield per plot $(20.42 \mathrm{~kg})$, fruit yield per hectare (567.15 qt.), maximum titrable acidity ( $0.38 \%)$, TSS (5.22\%), ascorbic acid $(22.81 \mathrm{mg} / 100 \mathrm{gm})$, reducing sugars $(1.61 \%)$, non reducing sugars $(2.70 \%)$, totalsugars $(4.31 \%)$. The effect of different levels of zinc on yield and quality parameters of tomato indicated that the levels of zinc $\mathrm{Zn}_{3}\left(30 \mathrm{~kg} \mathrm{ZnSO}_{4} / \mathrm{ha}\right)$ recorded maximum fruit yield per plant $(1305.09 \mathrm{gm})$, fruit yield per plot $(18.26 \mathrm{~kg})$, fruit yield per hectare (507.43 qt.), maximum titrable acidity (0.36\%), TSS (4.77\%), ascorbic acid (22.04 mg/100gm), reducing sugars $(1.48 \%)$, non reducing sugars $(2.61 \%)$, total sugars $(4.09 \%)$. The interaction effect of different zinc solubilizers and levels of zinc on yield and quality parameters of tomato indicated that the $\mathrm{B}_{2} \mathrm{Zn}_{3}$ (Trichoderma viride $+30 \mathrm{~kg} \mathrm{ZnSO}_{4} / \mathrm{ha}$ ) recorded maximum fruit yield per plant (1698.33 gm), fruit yield per plot $(23.77 \mathrm{~kg})$, fruit yield per hectare $(660.27 \mathrm{qt}$.$) , maximum titrable acidity (0.43 \%)$, TSS $(5.39 \%)$, ascorbic acid $(23.35 \mathrm{mg} / 100 \mathrm{gm})$, reducing sugars $(1.71 \%)$, non reducing sugars $(2.80 \%)$, total sugars $(4.51 \%)$.
\end{abstract}

Key Words : Tomato, Shivam, Zinc, Trichoderma viride, Pseudomonas strita, Yield, Quality

View Point Article : Galande, H. R., Bhosale, A.M., Syed, S. J. and Ahmadi, Basir Ahmad (2021). Studies on effects of graded levels of zinc and Trichoderma viride, Pseudomonas strita on yield and quality attributing characters in tomato (Lycopersicon esculentum L.). Internat. J. agric. Sci., 17 (AAEBSSD) : 1-12, DOI:10.15740/HAS/IJAS/17-AAEBSSD/1-12. Copyright@2021: Hind Agri-Horticultural Society.

Article History : Received : 05.07.2021; Accepted : 10.07.2021

\section{INTRODUCTION}

Vegetables are superfluous part of human nutrition. They are vital sources of proteins, vitamins, phosphorus, calcium, minerals, dietary fibers, micronutrients, antioxidants and phyto-chemicals in our daily diet. They are important adjunct for maintenance of good health and are beneficial in protecting against many degenerative diseases. Vegetable cultivation is one of

\footnotetext{
* Author for correspondence :

${ }^{1}$ Department of Horticulture, College of Agriculture (VNMKV) Latur (M.S.) India
} 
the major enterprises in horticulture which is becoming more popular due to the greater gratitude of their food values, nutritional value, vitamins and minerals. Tomato ( Lycopersicon esculentum L.) belonging to solanaceae family. Tomato is herbaceous plant with alternate leaves. The flowers are present in cluster on the stem between the nodes. Fruit of tomato is berry type, it has fleshy placenta and small kidney shaped seeds which are covered with short hairs. Tomato is a self pollinated crop. It is susceptible to high temperature, especially the large fruited fresh varieties. High night temperature may lead to lower fruit set of small and seedless fruit development. Most favorable temperature for fruit set is $25-30^{\circ} \mathrm{C}$. It is neither tolerate to frost nor to water logged condition. Tomato is rich in vitamin $\mathrm{C}$, it contains $20-25 \mathrm{mg} / 100 \mathrm{~g}$ and potassium is $200-210 \mathrm{mg} / 100 \mathrm{~g}$. Most of the tomato varieties vary in soluble solids from $4.5-7.00 \%$ and tomato seed contain $24 \%$ oil. Tomato contains Lycopene pigment which is a vital anti-oxidant that helps to fight against cancerous cell formation as well as other kind of health complications and diseases (Kumavat and Chaudhari, et al., 2013). Tomato contain 3 pigments i.e., for Red colour, Lycopene pigment present, for yellow colour, Carotenoids pigment ( $\beta$-carotene) and for Tangerine colour, Pro-Lycopene (cis-Lycopene) pigment is there. Tomato contains 18 gm calories, 0.9 grams protein, 3.9 gram carbohydrates, 2.6 grams sugars, 1.2 gram fiber, 0.2 gram fat and $95 \%$ water per $100 \mathrm{~g}$ weight of fruit. Tomato also contain a vit. K1 (phylloquinone) which is important for blood clotting and bone health and vit. B9 (foliate) which is important for normal tissue growth and cell function, it's particularly important for pregnant women.Fertilizer play important role in tomato yield and quality. Macro essential nutrient $(\mathrm{N}, \mathrm{P}, \mathrm{K})$ and some Micro nutrients such as ( B, Cu, \& $\mathrm{Zn})$ are very important for enzymatic reactions with a plants body such as the making of RNA \& DNA, Protein formation , synthesis of cell wall, occurrence of flowering and fruit formation, quality of plants. Zinc is an essential Micronutrient required for plants, animals and humans for their normal healthy growth and reproduction. In plants, zinc plays a key role as a structural constituent or regulatory co-factor which contents a wide range of different enzymes and protein in many important biochemical pathways are these are mainly concerned with carbohydrate metabolism, both in photosynthesis and in the conversion of sugarss to starch and protein metabolism.(Samreen et al.,2017)
Zinc is one of the most important essential micronutrients required in the range of 5 to $100 \mathrm{mg} \mathrm{kg}^{-1}$ concentrations in tissues for the management of nutrients, growth and reproduction of plants (Samreen, et al.,2017; Sharma, et al., 2013; Gotetiet al., 2013). Zinc deficiency is the major constraints in obtaining high yield and quality of tomato. Zinc reported to play a vital role in modifying the growth and development of many horticultural crops (Sathiyamurthy, 2017). Few zinc solubilizing bacterial genera viz. Bacillus spp., Pseudomonas spp., Thiobacillus spp., etc. and facultative thermophilic iron oxidizers were reported as zinc solubilizers. Pseudomonas sp. is omnipresent bacteria in agricultural soils and has many traits that make them well suited as zinc solubilisation. Pseudomonas strain used to suppress soil borne diseases and promote plant growth. Pseudomonas has been used for their beneficial effects on plant growth. Pseudomonas whose beneficial effects on the plant result from different mechanism i.e. direct mechanism (Solubilization of phosphorus, potassium, zinc, nitrogen fixation, sequestration of iron by siderophores, production of growth regulators etc.) or indirect mechanisms such as antibiotic production. Pseudomonas spp. was reported for promoting zinc and phosphorus bioavailability to plants which are globally widespread micronutrient deficiencies (Shahid, et al., 2020). Pseudomonas when used as fertilizers for the crops, they promotes mechanisms like production of Phytoharmones and insoluble mineral solubilisation that influenced root and shoot growth, tissue differentiation and they responses to the associated abiotic factors for this purpose.

\section{Material AND Methods}

The field experiment entitled "Studies on effects of graded levels of zinc and Trichoderma viride, Pseudomonas strita on yield and quality attributing characters in tomato (Lycopersicon esculentum L.)" cv. Shivam" was carried out during summer season, 2021 at Dept. of Horticulture, COA, VNMKV Parbhani. The field trial was laid out in Factorial RBD with 12 treatments and three replications Distance between two treatments and replications $(50 \mathrm{~cm}$ and $1.6 \mathrm{~m}$, respectively). The size of plot was $4.5 \mathrm{~m} \times 0.8 \mathrm{~m}$. spacing adopted was $60 \mathrm{~cm} \times 60 \mathrm{~cm}$. Experimental field was laid out as per the plan after preparation of land. The layout consisted of 36 experimental units. 
Studies on effects of graded levels of zinc \& Trichoderma viride, Pseudomonas strita on yield \& quality attributing characters in tomato

\begin{tabular}{|lcc|}
\hline \multicolumn{2}{|l|}{ Treatment details } \\
\hline Sr. No. & Treatment & \\
\hline Factor & & \\
& Treatment details \\
& $\mathrm{B}_{0}$ & Control \\
& $\mathrm{B}_{1}$ & Pseudomonas strita (liquid) \\
& $\mathrm{B}_{2}$ & Trichoderma viride (liquid) \\
B & & \\
& Levels of zinc $(\mathrm{kg} / \mathrm{ha})$ & $00 \mathrm{~kg} / \mathrm{ha}$ \\
& $\mathrm{Zn}_{0}$ & $10 \mathrm{~kg} / \mathrm{ha}$ \\
& $\mathrm{Zn}_{1}$ & $20 \mathrm{~kg} / \mathrm{ha}$ \\
$\mathrm{Zn}_{2}$ & $30 \mathrm{~kg} / \mathrm{ha}$ \\
& $\mathrm{Zn}_{3}$ & \\
\hline
\end{tabular}

\begin{tabular}{|ll|}
\hline Treatment No. & Treatment combination \\
\hline $\mathrm{T}_{1}$ & Control : Control \\
$\mathrm{T}_{2}$ & Control $: 10 \mathrm{~kg} \mathrm{ZnSO} / \mathrm{ha}$. \\
$\mathrm{T}_{3}$ & Control $: 20 \mathrm{~kg} \mathrm{ZnSO} /$ ha. \\
$\mathrm{T}_{4}$ & Control $: 30 \mathrm{~kg} \mathrm{ZnSO} /$ ha. \\
$\mathrm{T}_{5}$ & Pseudomonas strita $:$ Control \\
$\mathrm{T}_{6}$ & Pseudomonas strita $: 10 \mathrm{~kg} \mathrm{ZnSO} / \mathrm{ha}$. \\
$\mathrm{T}_{7}$ & Pseudomonas strita $: 20 \mathrm{~kg} \mathrm{ZnSO} / / \mathrm{ha}$. \\
$\mathrm{T}_{8}$ & Pseudomonas strita $: 30 \mathrm{~kg} \mathrm{ZnSO} / \mathrm{ha}$. \\
$\mathrm{T}_{9}$ & Trichoderma viride $:$ Control \\
$\mathrm{T}_{10}$ & Trichoderma viride: $10 \mathrm{~kg} \mathrm{ZnSO} / \mathrm{ha}$. \\
$\mathrm{T}_{11}$ & Trichoderma viride: $20 \mathrm{~kg} \mathrm{ZnSO} / \mathrm{ha}$. \\
$\mathrm{T}_{12}$ & Trichoderma viride: $30 \mathrm{~kg} \mathrm{ZnSO} / \mathrm{ha}$. \\
\hline
\end{tabular}

\section{Treatments and fertilizer application:}

Recommended dose Nitrogen, phosphorus and potash were applied through urea, single superphosphate and muriate of potash, at $250 \mathrm{~kg} \mathrm{~N} / \mathrm{ha}, 250 \mathrm{~kg} \mathrm{P} \mathrm{O}_{5} / \mathrm{ha}$ and $250 \mathrm{~kg} \mathrm{~K}{ }_{2} \mathrm{O} / \mathrm{ha}$. respectively. Chemical fertilizers, full dose of $\mathrm{P}_{2} \mathrm{O}_{5}$ and $\mathrm{K}_{2} \mathrm{O}$ were applied respectively through single super phosphate and muriate of potash at the 8 DAT in the rows while application of nitrogen was made through urea was in two equal split doses i.e. $50 \%$ at the 8 DAT and remaining 50\% at the time of flowering. Quantity of fertilizers applied per plot was common and uniform. Fertilizers were applied at the depth of $5 \mathrm{~cm}$ and were properly mixed with soil. Plots were irrigated immediately after application of fertilizers. Pseudomonas strita (1 lit/ha) and Trichoderma viride (1 liter/ha) was applied as per treatments (Drenching at 15 DAT) zinc sulphate was applied as per treatments (soil application at 15 DAT).

\section{Raising the nursery:}

The seeds of tomato were sown in pro tray filled with coco peat. After germination, 21-25 days old seedlings with well root development and uniform growth were selected and used transplanting.

\section{Seedling treatment:}

Tomato seedlings were treated with mixture of Pseudomonas strita + Trichoderma viride. The seedlings were treated with mixture of Pseudomonas strita + Trichoderma viride by dipping $20 \mathrm{~min}$. and after that remove seedlings from solution and then immediately after that transplanting is done.

\section{Observations recorded:}

Five plants were randomly selected from each of 36 plots and were labeled. The following observations were recorded on the different characters which are given as follows.

\section{Yield parameters :}

Fruit yield per plant:

Fruit weight of all the pickings and by averaging and was expressed in grams per plant.

Fruit yield per plot:

Fruit yield per plot was recorded as the weight of whole fruits per plot and was expressed in kilograms.

\section{Fruit yield per hectare:}

Fruit yield per hectare was calculated by converting the fruit yield per plot into hectare and expressed was quintal.

\section{Quality parameters :}

Titratable acidity :

Titratable acidity was determined according to the AOAC official method 942.15 (AOAC, 2000). Five gram of tomato juice diluted in $25 \mathrm{ml}$ of distilled water and titrated by $0.1 \mathrm{~N}$ sodium hydroxide $(\mathrm{NaOH})$ to $\mathrm{pH} 8.1$. The titratable acidity was expressed as g citric acid $/ \mathrm{kg}$ tomato, according to the following equation:

Titratable acidity (g citric $\mathrm{acid} / \mathrm{kg}$ tomato)

$=(\mathrm{V} \times \mathbf{0 . 1} \times \mathbf{1 0 0 0} \times \mathbf{0 . 0 6 4}) / \mathrm{m}$

Where: 0.1 is normality of $\mathrm{NaOH}(\mathrm{N}), 0.064$ is conversion factor of citric acid, $\mathrm{V}$ is the volume of $\mathrm{NaOH}$ required $(\mathrm{ml})$ and $\mathrm{m}$ is mass of tomato juice sample used (g).

Total soluble solids (TSS) :

Total soluble solids were measured by Erma hand 
refractometer ( $0-32 \%)$ by taking a drop of juice on prism of refractometer and the reading was recorded as total soluble solid in percent and after computing the mean value it was recorded as a TSS value of fruits for each treatment.

\section{Ascorbic acid :}

Determination of ascorbic acid was done by 2,6 dichlorophenol indophenols dye method as described by Ranganna (1977). A known quantity of tomato juice with $3 \%$ metaphosphoric acid $\left(\mathrm{HPO}_{3}\right)$ to make the final volume of $100 \mathrm{ml}$ and then filtered. A known quantity of aliquot was titrated against $0.025 \%$. 2,6 dichlorophenol indophenols dye to a pink colour end point. The ascorbic acid content of the sample was calculated taking into consideration the dye factor and expressed as $\mathrm{mg}$ ascorbic acid per $100 \mathrm{~g}$ juice extract.

$$
\begin{array}{cc}
\text { Dye factor }=\frac{0.5}{\text { Titrate reading }} & \\
\text { Ascorbic acid }(\mathrm{mg} / 100 \mathrm{gm})=\frac{\text { Titrate } x \text { Dye factor } x}{\text { Vol. made up reading }} \\
\begin{array}{c}
\text { Aliquot extract } x \\
\text { Weight of sample taken for estimation }
\end{array}
\end{array}
$$

\section{Reducing Sugars :}

Reducing sugars of juice was determined by method described by Ranganna (1986). A known quantity of sample was taken in a volumetric flask, some distilled water added and dissolved. Thereafter, $2 \mathrm{ml}$ of $45 \%$ basis lead acetate solution was added for clarification. After 10 minute, the solution delayed by adding potassium oxalate crystals remained undisclosed and volume made up to level with distilled water and filtrate was titrated against boiling standard Fehling's mixtures till the blue coloured appeared. Then 1-2 drops of methylene blue indicator was added and the titration was continued till the content attained a brick red colour and titrate value was noted. The percentage of reducing sugars was calculated according to following formula.

$$
\text { Reducing sugars }=\frac{\text { Glucose equivalent } \mathbf{x} \text { Total volume made up }}{\text { Titrate value } \mathbf{x} \text { Weight of sample }}
$$

\section{Non-Reducing Sugars:}

Non - Reducing sugars content was determined by using Benedict's method. It was expressed in per cent.

\section{Total Sugars:}

Total sugars were determined by adding the value of reducing and non-reducing sugars. It was expressed in per cent.

\section{RESUlts AND DisCUSSION}

The observations recorded on yield and quality characters along with the statistical test and their scientific interpretations are presented in this chapter under appropriate heads.

\section{Yield parameters:}

Yield of fruits per plant $(\mathrm{gm})$ :

The data pertaining to yield of fruits per plant influenced by different zinc solubilizing bacteria, different levels of zinc and their interaction effect is given in Table 1.

\section{Effetct of zinc solubilizers:}

The different zinc solubilizers resulted in significant differences in yield of fruits per plant of tomato. Maximum yield of fruits per plant (1458.76 gm) was observed in $\mathrm{B}_{2}$ (Trichoderma viride) which was at par with $\mathrm{B}_{1}$ (Pseudomonas strita) whereas, minimum yield of fruits per plant (909.36 gm) was observed in $\mathrm{B}_{0}$ (Control) in tomato.

The above result indicated that zinc solubilizers i.e. $\mathrm{B}_{2}$ (Trichoderma viride) recorded maximum yield of fruits per plant as compared to $\mathrm{B}_{1}$ (Pseudomonas strita) and $\mathrm{B}_{0}$ (Control). The Trichoderma virideimprove the hormonal characters of tomato. It enhance the chlorophyll synthesis and uptake of essential ions including N,P \& K which helps to setting of fruits and increasing the yield as compare to Pseudomonas strita and Control. These results were in conformity with the results obtained by Haque, et al.,(2012) in tomato where 50\% N + 50\% Trichoderma harzianum coated wheat grains increases yield of fruits per plant $(1.67 \mathrm{~kg})$ as compared to other treatments, Nzanza et al. (2012) in tomato where Trichoderma harzianum significantly increased yield of fruits per plant $(8.2 \mathrm{~kg})$ as compared to other treatments.

\section{Effect of levels of zinc:}

The different levels of zinc resulted in significant differences in yield of fruits per plant of tomato. Maximum yield of fruits per plant (1305.09 gm) was observed in $\mathrm{Zn}_{3}(30 \mathrm{~kg} \mathrm{ZnSO} / \mathrm{ha})$ which was at par with $\mathrm{Zn}_{2}(20 \mathrm{~kg}$ $\mathrm{ZnSO}_{4} / \mathrm{ha}$ ) in tomato whereas, minimum yield of fruits per plant (1006.76 gm) was observed in $\mathrm{Zn}_{0}($ Control) in tomato. 
Studies on effects of graded levels of zinc \& Trichoderma viride, Pseudomonas strita on yield \& quality attributing characters in tomato

The above result indicated that there was a increase in yield of fruits due to increase in the levels of zinc i.e. $\mathrm{Zn}_{3}\left(30 \mathrm{~kg} \mathrm{ZnSO}_{4} /\right.$ ha. $)$. Zinc is a essential micronutrient which responsible for maximizes fruit set and higher yield. Similar results were reported by Ali et al. (2015) in tomato where significantly increased yield of fruits per plant $(1.9 \mathrm{~kg})$ with increasing concentration of zinc at $25 \mathrm{ppm}$ as compared to other treatments.

\section{Interaction effect of zinc solubilizers and levels of} zinc:

It is evident from the data presented in a Table 2 that interaction effect of zinc solubilizers and levels of zinc was revealed to be significant on yield of fruits per plant in tomato. Maximum yield of fruits per plant (1698.33 gm) was observed in $\mathrm{B}_{2} \mathrm{Zn}_{3}$ which was at par with $\mathrm{B}_{2} \mathrm{Zn}_{2}$ and minimum yield of fruits per plant (855.11 $\mathrm{gm})$ was observed in $\mathrm{B}_{0} \mathrm{Zn}_{0}$ (Control) in tomato.

\section{Yield of fruits per plot $(\mathrm{kg})$ :}

The data pertaining to yield of fruits per plot influenced by different zinc solubilizing bacteria, different levels of zinc and their interaction effect is given in Table 2.

\section{Effect of zinc solubilizers :}

The different zinc solubilizers resulted in significant differences in yield of fruits per plot of tomato. Maximum

\begin{tabular}{|c|c|c|c|}
\hline Treatments & Yield of fruits per plant $(\mathrm{g})$ & Yield of fruits per plot $(\mathrm{kg})$ & Yield of fruits per hectare (ql.) \\
\hline \multicolumn{4}{|c|}{ Zinc Solubilizers (B) } \\
\hline & 909.36 & 12.72 & 353.45 \\
\hline & 1417.74 & 19.86 & 551.66 \\
\hline & 1458.76 & 20.42 & 567.15 \\
\hline S.E m \pm & 13.99 & 0.19 & 5.61 \\
\hline CD at $5 \%$ Level & 41.05 & 0.57 & 16.45 \\
\hline \multicolumn{4}{|c|}{ Levels of zinc ( $\mathrm{Zn})$} \\
\hline & 1006.76 & 14.09 & 391.38 \\
\hline & 1066.74 & 14.92 & 414.59 \\
\hline & 1257.71 & 17.60 & 488.88 \\
\hline & 1305.09 & 18.26 & 507.43 \\
\hline S.E m \pm & 16.16 & 0.22 & 6.47 \\
\hline $\mathrm{CD}$ at $5 \%$ Level & 47.40 & 0.66 & 18.99 \\
\hline \multicolumn{4}{|c|}{ Interaction $(\mathrm{B} \times \mathrm{Zn})$} \\
\hline $\mathrm{B}_{0} \mathrm{Zn}_{0}$ & 855.11 & 11.96 & 332.31 \\
\hline $\mathrm{B}_{0} \mathrm{Zn}_{1}$ & 900.33 & 12.60 & 349.90 \\
\hline $\mathrm{B}_{0} \mathrm{Zn}_{2}$ & 922.14 & 12.91 & 358.52 \\
\hline $\mathrm{B}_{0} \mathrm{Zn}_{3}$ & 959.84 & 13.43 & 373.05 \\
\hline $\mathrm{B}_{1} \mathrm{Zn}_{0}$ & 953.06 & 13.34 & 370.46 \\
\hline $\mathrm{B}_{1} \mathrm{Zn}_{1}$ & 990.29 & 13.85 & 384.73 \\
\hline $\mathrm{B}_{1} \mathrm{Zn}_{2}$ & 1005.56 & 14.08 & 390.92 \\
\hline $\mathrm{B}_{1} \mathrm{Zn}_{3}$ & 1257.12 & 17.60 & 488.98 \\
\hline $\mathrm{B}_{2} \mathrm{Zn}_{0}$ & 1212.12 & 16.97 & 471.39 \\
\hline $\mathrm{B}_{2} \mathrm{Zn}_{1}$ & 1309.61 & 18.33 & 509.16 \\
\hline $\mathrm{B}_{2} \mathrm{Zn}_{2}$ & 1614.96 & 22.60 & 627.77 \\
\hline $\mathrm{B}_{2} \mathrm{Zn}_{3}$ & 1698.33 & 23.77 & 660.27 \\
\hline S.E $\mathrm{m} \pm$ & 27.99 & 0.39 & 11.22 \\
\hline $\mathrm{CD}$ at $5 \%$ Level & 83.93 & 1.17 & 33.63 \\
\hline
\end{tabular}


yield of fruits per plot $\left(20.42 \mathrm{~kg}\right.$ ) was observed in $\mathrm{B}_{2}$ (Trichoderma viride) which was at par with $\mathrm{B}_{1}$ (Pseudomonas strita) whereas, minimum yield of fruits per plot $(12.72 \mathrm{~kg})$ was observed in $\mathrm{B}_{0}$ (Control) in tomato.

The above result indicated that zinc solubilizers i.e. $\mathrm{B}_{2}$ (Trichoderma viride) recorded maximum yield of fruits per plant as compared to $\mathrm{B}_{1}$ (Pseudomonas strita) and $\mathrm{B}_{0}$ (Control). The Trichoderma virideimprove the hormonal characters of tomato. It enhance the chlorophyll synthesis and uptake of essential ions including N,P \& K which helps to setting of fruits and increasing the yield as compare to Pseudomonas strita and Control. These results were in conformity with the results obtained by
Singh and Sharma et al. (2019) in chilli where $T_{20}$ increases yield of fruits per plot $(9.82 \mathrm{~kg})$ as compared to other treatments.

Effect of leverls of zinc:

The different levels of zinc resulted in significant differences in yield of fruits per plot of tomato. Maximum yield of fruits per plot $\left(18.26 \mathrm{~kg}\right.$ ) was observed in $\mathrm{Zn}_{3}$ (30 $\mathrm{kg} \mathrm{ZnSO} /$ ha) which was at par with $\mathrm{Zn}_{2}(20 \mathrm{~kg}$ $\mathrm{ZnSO}_{4} / \mathrm{ha}$ ) in tomato whereas, minimum yield of fruits per plot $\left(14.09 \mathrm{~kg}\right.$ ) was observed in $\mathrm{Zn}_{0}$ (Control) in tomato.

The above result indicated that there was a increase in yield of fruits due to increase in the levels of zinc i.e.

\begin{tabular}{|c|c|c|c|}
\hline Treatments & Titratable acidity (\%) & TSS (\%) & Ascorbic acid (mg/100 g) \\
\hline \multicolumn{4}{|c|}{ Zinc Solubilizers (B) } \\
\hline & 0.30 & 3.45 & 20.16 \\
\hline & 0.37 & 5.20 & 22.78 \\
\hline & 0.38 & 5.22 & 22.81 \\
\hline S.E m + & 0.001 & 0.01 & 0.01 \\
\hline $\mathrm{CD}$ at $5 \%$ Level & 0.003 & 0.03 & 0.05 \\
\hline \multicolumn{4}{|c|}{ Levels of zinc (Zn) } \\
\hline & 0.31 & 3.96 & 20.50 \\
\hline & 0.32 & 4.18 & 21.38 \\
\hline & 0.35 & 4.75 & 21.99 \\
\hline & 0.36 & 4.77 & 22.04 \\
\hline S.E $m+$ & 0.001 & 0.01 & 0.02 \\
\hline $\mathrm{CD}$ at $5 \%$ Level & 0.003 & 0.03 & 0.06 \\
\hline \multicolumn{4}{|c|}{ Interaction $(\mathrm{B} \times \mathrm{Zn})$} \\
\hline $\mathrm{B}_{0} \mathrm{Zn}_{0}$ & 0.29 & 3.07 & 19.45 \\
\hline $\mathrm{B}_{0} \mathrm{Zn}_{1}$ & 0.30 & 3.23 & 19.83 \\
\hline $\mathrm{B}_{0} \mathrm{Zn}_{2}$ & 0.30 & 3.61 & 20.48 \\
\hline $\mathrm{B}_{0} \mathrm{Zn}_{3}$ & 0.31 & 3.89 & 20.86 \\
\hline $\mathrm{B}_{1} \mathrm{Zn}_{0}$ & 0.30 & 3.82 & 20.36 \\
\hline $\mathrm{B}_{1} \mathrm{Zn}_{1}$ & 0.33 & 4.18 & 21.37 \\
\hline $\mathrm{B}_{1} \mathrm{Zn}_{2}$ & 0.35 & 4.90 & 21.66 \\
\hline $\mathrm{B}_{1} \mathrm{Zn}_{3}$ & 0.35 & 5.04 & 21.92 \\
\hline $\mathrm{B}_{2} \mathrm{Zn}_{0}$ & 0.35 & 4.99 & 21.71 \\
\hline $\mathrm{B}_{2} \mathrm{Zn}_{1}$ & 0.35 & 5.13 & 22.95 \\
\hline $\mathrm{B}_{2} \mathrm{Zn}_{2}$ & 0.42 & 5.33 & 23.25 \\
\hline $\mathrm{B}_{2} \mathrm{Zn}_{3}$ & 0.43 & 5.39 & 23.35 \\
\hline S.E $\mathrm{m}+$ & 0.002 & 0.02 & 0.03 \\
\hline CD at $5 \%$ Level & 0.006 & & 0.11 \\
\hline
\end{tabular}


Studies on effects of graded levels of zinc \& Trichoderma viride, Pseudomonas strita on yield \& quality attributing characters in tomato

$\mathrm{Zn}_{3}(30 \mathrm{~kg} \mathrm{ZnSO} / \mathrm{ha}$.). Zinc is a essential micronutrient which responsible for maximizes fruit set and higher yield. Similar results were reported by Ali et al. (2015) in tomato where significantly increased yield of fruits per plot $(25.71 \mathrm{~kg})$ with increasing concentration of zinc at $25 \mathrm{ppm}$ as compared to other treatments.

\section{Interaction effect of zinc solubilizers and levels of zinc :}

It is evident from the data presented in a Table 2 that interaction effect of zinc solubilizers and levels of zinc was revealed to be significant on yield of fruits per plot in tomato. Maximum yield of fruits per plot (23.77 $\mathrm{kg}$ ) was observed in $\mathrm{B}_{2} \mathrm{Zn}_{3}$ which was at par with $\mathrm{B}_{2} \mathrm{Zn}_{2}$ and minimum yield of fruits per plot $(11.96 \mathrm{~kg})$ was observed in $\mathrm{B}_{0} \mathrm{Zn}_{0}$ (Control) in tomato.

\section{Yield of fruits per hectace (quintal) :}

The data pertaining to yield of fruits per hectare influenced by different zinc solubilizing bacteria, different levels of zinc and their interaction effect is given in Table 2.

\section{Effect of zinc solubilizers :}

The different zinc solubilizers resulted in significant differences in yield of fruits per hectare of tomato. Maximum yield of fruits per hectare (567.15 qt.) was observed in $\mathrm{B}_{2}$ (Trichoderma viride) which was at par with $\mathrm{B}_{1}$ (Pseudomonas strita) whereas, minimum yield of fruits per hectare (353.45 qt.) was observed in $\mathrm{B}_{0}$ (Control) in tomato.

The above result indicated that zinc solubilizers i.e. $\mathrm{B}_{2}$ (Trichoderma viride) recorded maximum yield of fruits per hectare as compared to $\mathrm{B}_{1}$ (Pseudomonas strita) and $\mathrm{B}_{0}$ (Control). The Trichoderma viride improve the hormonal characters of tomato. It enhances the chlorophyll synthesis and uptake of essential ions including N, P \& K as compared to P. strita and Control. These results were in conformity with the results obtained by Singh and Sharma, et al.,(2019) in chilli where $T_{20}$ increases yield of fruits per hectare (102.03 qt.) as compared to other treatments, Sujata Kumari et al. (2019) in bell pepper where yield of fruits per ha. Significantly increased by $T$. harzianum (403.17 qt.) as compared to other treatments.

\section{Effect of levels of zinc:}

The different levels of zinc resulted in significant differences in yield of fruits per hectare of tomato. Maximum yield of fruits per hectare (507.43) was observed in $\mathrm{Zn}_{3}(30 \mathrm{~kg} \mathrm{ZnSO} / \mathrm{ha}$ ) which was at par with $\mathrm{Zn}_{2}\left(20 \mathrm{~kg} \mathrm{ZnSO}_{4} / \mathrm{ha}\right)$ in tomato whereas, minimum yield of fruits per hectare (391.38 qt.) was observed in $\mathrm{Zn}_{0}$ (Control) in tomato.

The above result indicated that there was a increase in yield of fruits due to increase in the levels of zinc i.e. $\mathrm{Zn}_{3}$ (30 kg ZnSO$/$ ha.). Zinc is a essential micronutrient which responsible for maximizes fruit set and higher yield. Similar results were reported by Ali et al. (2015) in tomato where significantly increased yield of fruits per hectare (58.3 ton) with increasing concentration of zinc at $25 \mathrm{ppm}$ as compared to other treatments, Ullah et al. (2015) in tomato where significantly increased yield per ha. (23.40 t/ha.) with increasing the level of zinc at $0.4 \%$ as compared to other treatments.

\section{Interaction effect of zinc solubilizers and levels of zinc :}

It is evident from the data presented in a Table 2 that interaction effect of zinc solubilizers and levels of zinc was revealed to be significant on yield of fruits per hectare in tomato. Maximum yield of fruits per hectare (660.27 qt.) was observed in $\mathrm{B}_{2} \mathrm{Zn}_{3}$ which was at par with $\mathrm{B}_{2} \mathrm{Zn}_{2}$ and minimum yield of fruits per hectare (332.23 qt.) was observed in $\mathrm{B}_{0} \mathrm{Zn}_{0}$ (Control) in tomato.

\section{Quality parameters:}

Titratable acidity (\%):

The data pertaining to titratable acidity influenced by different zinc solubilizing bacteria, different levels of zinc and their interaction effect is given in Table 3 .

\section{Effect of zinc solubilizers:}

The different zinc solubilizers resulted in significant differences in titratable acidity of tomato. Maximum titratable acidity $(0.38 \%)$ was observed in $\mathrm{B}_{2}$ (Trichoderma viride) which was at par with $\mathrm{B}_{1}$ (Pseudomonas strita) whereas, minimum titratable acidity $(0.30 \%)$ was observed in $\mathrm{B}_{0}(\mathrm{Control})$ in tomato.

The above result indicated that zinc solubilizers i.e. $\mathrm{B}_{2}$ (Trichoderma viride) recorded maximum titratable acidity as compared to $\mathrm{B}_{1}$ (Pseudomonas strita) and $\mathrm{B}_{0}$ (Control). The Trichoderma viride improve the biochemical characters of tomato. It helps to accumulation of proline, flavonoids as compare to Pseudomonas strita and Control. These results were 
in conformity with the results obtained by Haque, et al.,(2012) in tomato where $50 \% \mathrm{~N}+50 \%$ Trichoderma harzianum coated wheat grains increases titratable acidity as compared to other treatments.

\section{Effect of levels of zinc:}

The different levels of zinc resulted in significant differences in titratable acidity of tomato. Maximum titratable acidity $(0.36 \%)$ was observed in $\mathrm{Zn}_{3}(30 \mathrm{~kg}$ $\left.\mathrm{ZnSO}_{4} / \mathrm{ha}\right)$ which was at par with $\mathrm{Zn}_{2}\left(20 \mathrm{~kg} \mathrm{ZnSO}_{4} / \mathrm{ha}\right)$ in tomato whereas, minimum titratable acidity $(0.31 \%)$ was observed in $\mathrm{Zn}_{0}$ (Control) in tomato.
The above result indicated that there was a increase in titratable acidity due to increase in the levels of zinc i.e. $\mathrm{Zn}_{3}$ (30 $\mathrm{kg} \mathrm{ZnSO}_{4} / \mathrm{ha}$.). Zinc is a essential micronutrient which responsible for biochemical parameters. Similar results were reported by Salam, et al., (2010) in tomato where significantly increased titratable acidity $(0.47 \%)$ with increasing concentration of zinc at $6 \mathrm{~kg} / \mathrm{ha}$ as compared to other treatments, Prasad and Subbarayappa et al. (2018) in tomato where significantly increased titratable acidity $(0.40 \%)$ with increasing concentration of zinc at $20 \mathrm{~kg} / \mathrm{ha}$ as compared to other treatments.

\begin{tabular}{|c|c|c|c|}
\hline Treatments & Reducing Sugars (\%) & Non-Reducing Sugars (\%) & Total Sugars (\%) \\
\hline \multicolumn{4}{|c|}{ Zinc Solubilizers (B) } \\
\hline $\mathrm{B}_{0}$ & 1.28 & 2.32 & 3.60 \\
\hline $\mathrm{B}_{1}$ & 1.60 & 2.69 & 4.30 \\
\hline $\mathrm{B}_{2}$ & 1.61 & 2.70 & 4.31 \\
\hline S.E $\mathrm{m} \pm$ & 0.004 & 0.004 & 0.000 \\
\hline $\mathrm{CD}$ at $5 \%$ Level & 0.01 & 0.01 & 0.001 \\
\hline \multicolumn{4}{|c|}{ Levels of zinc $(\mathrm{Zn})$} \\
\hline $\mathrm{Zn}_{0}$ & 1.30 & 2.35 & 3.67 \\
\hline $\mathrm{Zn}_{1}$ & 1.42 & 2.47 & 3.89 \\
\hline $\mathrm{Zn}_{2}$ & 1.47 & 2.60 & 4.08 \\
\hline $\mathrm{Zn}_{3}$ & 1.48 & 2.61 & 4.09 \\
\hline S.E m + & 0.004 & 0.005 & 0.001 \\
\hline $\mathrm{CD}$ at $5 \%$ Level & 0.01 & 0.01 & 0.002 \\
\hline \multicolumn{4}{|c|}{ Interaction $(\mathrm{B} \times \mathrm{Zn})$} \\
\hline $\mathrm{B}_{0} \mathrm{Zn}_{0}$ & 1.24 & 2.21 & 3.45 \\
\hline $\mathrm{B}_{0} \mathrm{Zn}_{1}$ & 1.29 & 2.28 & 3.57 \\
\hline $\mathrm{B}_{0} \mathrm{Zn}_{2}$ & 1.29 & 2.37 & 3.66 \\
\hline $\mathrm{B}_{0} \mathrm{Zn}_{3}$ & 1.31 & 2.42 & 3.73 \\
\hline $\mathrm{B}_{1} \mathrm{Zn}_{0}$ & 1.29 & 2.38 & 3.67 \\
\hline $\mathrm{B}_{1} \mathrm{Zn}_{1}$ & 1.33 & 2.44 & 3.77 \\
\hline $\mathrm{B}_{1} \mathrm{Zn}_{2}$ & 1.36 & 2.50 & 3.86 \\
\hline $\mathrm{B}_{1} \mathrm{Zn}_{3}$ & 1.42 & 2.63 & 4.05 \\
\hline $\mathrm{B}_{2} \mathrm{Zn}_{0}$ & 1.40 & 2.49 & 3.89 \\
\hline $\mathrm{B}_{2} \mathrm{Zn}_{1}$ & 1.65 & 2.72 & 4.37 \\
\hline $\mathrm{B}_{2} \mathrm{Zn}_{2}$ & 1.68 & 2.79 & 4.50 \\
\hline $\mathrm{B}_{2} \mathrm{Zn}_{3}$ & 1.71 & 2.80 & 4.51 \\
\hline S.E m + & 0.007 & 0.008 & 0.001 \\
\hline CD at $5 \%$ Level & 0.02 & & 0.003 \\
\hline
\end{tabular}


Studies on effects of graded levels of zinc \& Trichoderma viride, Pseudomonas strita on yield \& quality attributing characters in tomato

Interaction effect of zinc solubilizers and levels of zinc:

It is evident from the data presented in a Table 3 that interaction effect of zinc solubilizers and levels of zinc was revealed to be significant on titratable acidity in tomato. Maximum titratable acidity $(0.43 \%)$ was observed in $\mathrm{B}_{2} \mathrm{Zn}_{3}$ which was at par with $\mathrm{B}_{2} \mathrm{Zn}_{2}$ and minimum titratable acidity $(0.29 \%)$ was observed in $\mathrm{B}_{0} \mathrm{Zn}_{0}$ (Control) in tomato.

Total soluble solids (TSS) (\%):

The data pertaining to TSS influenced by different zinc solubilizing bacteria, different levels of zinc and their interaction effect is given in Table 3.

\section{Effect of zinc solubilizers:}

The different zinc solubilizers resulted in significant differences in TSS of tomato. Maximum TSS (5.22\%) was observed in $\mathrm{B}_{2}$ (Trichoderma viride) which was at par with $\mathrm{B}_{1}$ (Pseudomonas strita) whereas, minimum TSS $(3.45 \%)$ was observed in $\mathrm{B}_{0}$ (Control) in tomato.

The above result indicated that zinc solubilizers i.e. $\mathrm{B}_{2}$ (Trichoderma viride) recorded maximum TSS as compared to $\mathrm{B}_{1}$ (Pseudomonas strita) and $\mathrm{B}_{0}$ (Control). The Trichoderma viride improve the biochemical characters of tomato. It helps to accumulation of proline, flavonoids as compare to Pseudomonas strita and Control. These results were in conformity with the results obtained by Molla, et al.,(2012) in tomato where Trichoderma-enriched biofertilizer increases TSS $\left(7.13^{\circ}\right.$ brix) as compared to other treatments, Amit kumar, et al., (2019) in onion where Trichoderma and Azotobacter significantly increased TSS ( $13.67^{\circ}$ brix $)$ as compared to other treatments.

\section{Effect of levels of zinc:}

The different levels of zinc resulted in significant differences in TSS of tomato. Maximum TSS (4.77\%) was observed in $\mathrm{Zn}_{3}\left(30 \mathrm{~kg} \mathrm{ZnSO}_{4} / \mathrm{ha}\right.$ ) which was at par with $\mathrm{Zn}_{2}(20 \mathrm{~kg} \mathrm{ZnSO} / \mathrm{ha})$ in tomato whereas, minimum TSS (3.96\%) was observed in $\mathrm{Zn}_{0}$ (Control) in tomato.

The above result indicated that there was a increase in TSS due to increase in the levels of zinc i.e. $\mathrm{Zn}_{3}(30$ $\mathrm{kg} \mathrm{ZnSO} /$ ha.). Zinc is a essential micronutrient which responsible for biochemical parameters. Similar results were reported by Salam et al. (2010) in tomato where significantly increased TSS $(4.50 \%)$ with increasing concentration of zinc at $6 \mathrm{~kg} / \mathrm{ha}$ as compared to other treatments, Prasad and Subbarayappa et al. (2018) in tomato where significantly increased $\operatorname{TSS}\left(5.90^{\circ} \mathrm{brix}\right)$ with increasing concentration of zinc at $20 \mathrm{~kg} / \mathrm{ha}$ as compared to other treatments.

\section{Interaction effect of zinc solubilizers and levels of zinc:}

It is evident from the data presented in a Table 3 that interaction effect of zinc solubilizers and levels of zinc was revealed to be significant on TSS in tomato. Maximum TSS (5.39\%) was observed in $\mathrm{B}_{2} \mathrm{Zn}_{3}$ which was at par with $\mathrm{B}_{2} \mathrm{Zn}_{2}$ and minimum TSS (3.07\%) was observed in $\mathrm{B}_{0} \mathrm{Zn}_{0}$ (Control) in tomato.

\section{Ascorbic acid (mg/100gm):}

The data pertaining to ascorbic acid influenced by different zinc solubilizing bacteria, different levels of zinc and their interaction effect is given in Table 3.

\section{Effect of zinc solubilizers:}

The different zinc solubilizers resulted in significant differences in ascorbic acid of tomato. Maximum ascorbic acid $(22.81 \mathrm{mg} / 100 \mathrm{~g})$ was observed in $\mathrm{B}_{2}$ (Trichoderma viride) which was at par with $\mathrm{B}_{1}$ (Pseudomonas strita) whereas, minimum ascorbic acid $(20.16 \mathrm{mg} / 100 \mathrm{~g})$ was observed in $\mathrm{B}_{0}(\mathrm{Control})$ in tomato.

The above result indicated that zinc solubilizers i.e. $\mathrm{B}_{2}$ (Trichoderma viride) recorded maximum ascorbic acid as compared to $\mathrm{B}_{1}$ (Pseudomonas strita) and $\mathrm{B}_{0}$ (Control). The Trichoderma viride improve the biochemical characters of tomato. It helps to accumulation of proline, flavonoids as compare to Pseudomonas strita and Control. These results were in conformity with the results obtained by Molla, et al.,(2012) in tomato where Trichoderma-enriched biofertilizer increases ascorbic acid $(22.18 \mathrm{mg} / 100 \mathrm{~g})$ as compared to other treatments, Nzanza et al. (2012) in tomato where Trichoderma harzianum and AMF significantly increased ascorbic acid $(28.3 \mathrm{mg} / 100 \mathrm{~g})$ as compared to other treatments.

\section{Effect of levels of zinc:}

The different levels of zinc resulted in significant differences in ascorbic acid of tomato. Maximum ascorbic acid $(22.04 \mathrm{mg} / 100 \mathrm{~g})$ was observed in $\mathrm{Zn}_{3}(30$ $\mathrm{kg} \mathrm{ZnSO} / \mathrm{ha})$ which was at par with $\mathrm{Zn}_{2}(20 \mathrm{~kg} \mathrm{ZnSO} /$ ha) in tomato whereas, minimum ascorbic acid (20.50 
$\mathrm{mg} / 100 \mathrm{~g}$ ) was observed in $\mathrm{Zn}_{0}$ (Control) in tomato.

The above result indicated that there was a increase in ascorbic acid due to increase in the levels of zinc i.e. $\mathrm{Zn}_{3}$ (30 $\mathrm{kg} \mathrm{ZnSO}_{4} /$ ha.). Zinc is a essential micronutrient which responsible for biochemical parameters. Similar results were reported by Prasad and Subbarayappa, et al. (2018) in tomato where significantly increased ascorbic acid (47.19 mg/100g) with increasing concentration of zinc at $20 \mathrm{~kg} / \mathrm{ha}$ as compared to other treatments, Rahman, et al., (2019) in tomato where significantly increased ascorbic acid $(114.1 \mathrm{mg} / 100 \mathrm{~g})$ with increasing the concentration of zinc at $0.5 \mathrm{~kg} / \mathrm{ha}$.

\section{Interaction effect of zinc solubilizers and levels of zinc:}

It is evident from the data presented in a Table 3 that interaction effect of zinc solubilizers and levels of zinc was revealed to be significant on ascorbic acid in tomato. Maximum ascorbic acid $(23.35 \mathrm{mg} / 100 \mathrm{~g})$ was observed in $\mathrm{B}_{2} \mathrm{Zn}_{3}$ which was at par with $\mathrm{B}_{2} \mathrm{Zn}_{2}$ and minimum ascorbic acid $(19.45 \mathrm{mg} / 100 \mathrm{~g})$ was observed in $\mathrm{B}_{0} \mathrm{Zn}_{0}$ (Control) in tomato.

\section{Reducing sugar (\%):}

The data pertaining to reducing sugar influenced by different zinc solubilizing bacteria, different levels of zinc and their interaction effect is given in Table 3.

\section{Effect of zinc solubilizers:}

The different zinc solubilizers resulted in significant differences in reducing sugar of tomato. Maximum reducing sugar $(1.61 \%)$ was observed in $\mathrm{B}_{2}$ (Trichoderma viride) which was at par with $\mathrm{B}_{1}$ (Pseudomonas strita) whereas, minimum reducing sugar $(1.28 \%)$ was observed in $\mathrm{B}_{0}$ (Control) in tomato.

The above result indicated that zinc solubilizers i.e. $\mathrm{B}_{2}$ (Trichoderma viride) recorded maximum reducing sugar as compared to $\mathrm{B}_{1}$ (Pseudomonas strita) and $\mathrm{B}_{0}$ (Control). The Trichoderma viride improve the biochemical characters of tomato. It helps to accumulation of sugar and soluble proteins as compare to Pseudomonas strita and Control. These results were in conformity with the results obtained by Molla et al. (2012) in tomato where Trichoderma-enriched biofertilizer increases reducing sugar as compared to other treatments.

Effect of levels of zinc:

The different levels of zinc resulted in significant differences in reducing sugar of tomato. Maximum reducing sugar $(1.48 \%)$ was observed in $\mathrm{Zn}_{3}(30 \mathrm{~kg}$ $\mathrm{ZnSO}_{4} / \mathrm{ha}$ ) which was at par with $\mathrm{Zn}_{2}\left(20 \mathrm{~kg} \mathrm{ZnSO}_{4} / \mathrm{ha}\right)$ in tomato whereas, minimum reducing sugar $(1.30 \%)$ was observed in $\mathrm{Zn}_{0}$ (Control) in tomato.

The above result indicated that there was a increase in reducing sugar due to increase in the levels of zinc i.e. $\mathrm{Zn}_{3}$ (30 $\mathrm{kg} \mathrm{ZnSO}_{4} /$ ha.). Zinc is a essential micronutrient which responsible for biochemical parameters. Similar results were reported by Meena, et al., (2015) in tomato where significantly increased reducing sugar $(2.80 \%)$ with increasing concentration of zinc at $100 \mathrm{ppm}$ as compared to other treatments.

\section{Interaction effect of zinc solubilizers levels of zinc:}

It is evident from the data presented in a Table 3 that interaction effect of zinc solubilizers and levels of zinc was revealed to be significant on reducing sugar in tomato. Maximum reducing sugar $(1.71 \%)$ was observed in $\mathrm{B}_{2} \mathrm{Zn}_{3}$ which was at par with $\mathrm{B}_{2} \mathrm{Zn}_{2}$ and minimum reducing sugar (1.24\%) was observed in $\mathrm{B}_{0} \mathrm{Zn}_{0}$ (Control) in tomato.

Non-reducing sugar (\%):

The data pertaining to non-reducing sugar influenced by different zinc solubilizing bacteria, different levels of zinc and their interaction effect is given in Table 3.

\section{Effect of zinc solubilizers:}

The different zinc solubilizers resulted in significant differences in non-reducing sugar of tomato. Maximum non-reducing sugar $(2.70 \%)$ was observed in $\mathrm{B}_{2}$ (Trichoderma viride) which was at par with $\mathrm{B}_{1}$ (Pseudomonas strita) whereas, minimum non-reducing sugar $(2.32 \%)$ was observed in $\mathrm{B}_{0}$ (Control) in tomato.

The above result indicated that zinc solubilizers i.e. $\mathrm{B}_{2}$ (Trichoderma viride) recorded maximum nonreducing sugar as compared to $\mathrm{B}_{1}$ (Pseudomonas strita) and $\mathrm{B}_{0}(\mathrm{Control})$. The Trichoderma virideimprove the biochemical characters of tomato. It helps to accumulation of sugar and soluble proteins as compare to Pseudomonas strita and Control. These results were in conformity with the results obtained by Molla et al.,(2012) in tomato where Trichoderma-enriched biofertilizer increases non-reducing sugar as compared to other treatments.

Effect of levels of zinc:

The different levels of zinc resulted in significant 
Studies on effects of graded levels of zinc \& Trichoderma viride, Pseudomonas strita on yield \& quality attributing characters in tomato

differences in non-reducing sugar of tomato. Maximum non-reducing sugar $(2.61 \%)$ was observed in $\mathrm{Zn}_{3}(30 \mathrm{~kg}$ $\mathrm{ZnSO}_{4} / \mathrm{ha}$ ) which was at par with $\mathrm{Zn}_{2}\left(20 \mathrm{~kg} \mathrm{ZnSO}_{4} / \mathrm{ha}\right)$ in tomato whereas, minimum non-reducing sugar $(2.35 \%)$ was observed in $\mathrm{Zn}_{0}$ (Control) in tomato.

The above result indicated that there was a increase in non-reducing sugar due to increase in the levels of zinc i.e. $\mathrm{Zn}_{3}\left(30 \mathrm{~kg} \mathrm{ZnSO}_{4} / \mathrm{ha}\right.$.). Zinc is a essential micronutrient which responsible for biochemical parameters. Similar results were reported by Meena et al. (2015) in tomato where significantly increased nonreducing sugar $(0.94 \%)$ with increasing concentration of zinc at $100 \mathrm{ppm}$ as compared to other treatments.

\section{Interaction effect of zinc solubilizers and levels of zinc:}

It is evident from the data presented in a Table 3 that interaction effect of zinc solubilizers and levels of zinc was revealed to be significant on non-reducing sugar in tomato. Maximum non-reducing sugar $(2.80 \%)$ was observed in $\mathrm{B}_{2} \mathrm{Zn}_{3}$ which was at par with $\mathrm{B}_{2} \mathrm{Zn}_{2}$ and minimum non-reducing sugar $(2.21 \%)$ was observed in $\mathrm{B}_{0} \mathrm{Zn}_{0}$ (Control) in tomato.

\section{Tatal sugar (\%) :}

The data pertaining to total sugar influenced by different zinc solubilizing bacteria, different levels of zinc and their interaction effect is given in Table 3.

\section{Effect of zinc solubilizers:}

The different zinc solubilizers resulted in significant differences in total sugar of tomato. Maximum total sugar (4.31\%) was observed in $\mathrm{B}_{2}$ (Trichoderma viride) which was at par with $\mathrm{B}_{1}$ (Pseudomonas strita) whereas, minimum total sugar $(3.60 \%)$ was observed in $\mathrm{B}_{0}$ (Control) in tomato.

The above result indicated that zinc solubilizers i.e. $\mathrm{B}_{2}$ (Trichoderma viride) recorded maximum total sugar as compared to $\mathrm{B}_{1}$ (Pseudomonas strita) and $\mathrm{B}_{0}$ (Control). The Trichoderma viride improve the biochemical characters of tomato. It helps to accumulation ofsugar and soluble proteins as compare to Pseudomonas strita and Control. These results were in conformity with the results obtained by Molla et al.(2012) in tomato where Trichoderma-enriched biofertilizer increases total sugar $(5.11 \%)$ as compared to other treatments.
Effect of levels of zinc:

The different levels of zinc resulted in significant differences in total sugar of tomato. Maximum total sugar (4.09\%) was observed in $\mathrm{Zn}_{3}\left(30 \mathrm{~kg} \mathrm{ZnSO}_{4} /\right.$ ha) which was at par with $\mathrm{Zn}_{2}\left(20 \mathrm{~kg} \mathrm{ZnSO}_{4} / \mathrm{ha}\right)$ in tomato whereas, minimum total sugar $(3.67 \%)$ was observed in $\mathrm{Zn}_{0}$ (Control) in tomato.

The above result indicated that there was a increase in total sugar due to increase in the levels of zinc i.e. $\mathrm{Zn}_{3}$ ( $30 \mathrm{~kg} \mathrm{ZnSO}_{4} /$ ha.). Zinc is a essential micronutrient which responsible for biochemical parameters. Similar results were reported by Meena et al. (2015) in tomato where significantly increased total sugar $(3.93 \%)$ with increasing concentration of zinc at $100 \mathrm{ppm}$ as compared to other treatments.

\section{Interaction effect of zinc solubilizers and levels of zinc:}

It is evident from the data presented in a Table 3 that interaction effect of zinc solubilizers and levels of zinc was revealed to be significant on total sugar in tomato. Maximum total sugar (4.51\%) was observed in $\mathrm{B}_{2} \mathrm{Zn}_{3}$ which was at par with $\mathrm{B}_{2} \mathrm{Zn}_{2}$ and minimum nonreducing sugar (3.45\%) was observed in $\mathrm{B}_{0} \mathrm{Zn}_{0}$ (Control) in tomato.

\section{REFERENCES}

Ali, M.R., Mehraj, H. and Jamal Uddin, A.F.M. (2015). Effects of foliar application of zinc and boron on growth and yield of summer tomato. J. Biosci. Agric. Res, 6 (1) : 512-517.

Goteti, P.K., Emmanuel, L.D.A., Desai, S. and Shaik, M.H.A. (2013). Prospective zinc solubilising bacteria for enhanced nutrient uptake and growth promotion in maize (Zea mays L.). International Journal of microbiology, Article ID 869697, 17.

Haque, M.M., Ilias, G.N.M. and Molla, A.H. (2012). Impact of Trichoderma-enriched biofertilizer on the growth and yield of mustard (Brassica rapa L.) and tomato (Solanum lycopersicon Mill.). The Agriculturists A Scientific Journal of Krishi Foundation, 10(2):109-119.

Kumar, A., Meena, M.L., Shivran, B.C., Pal, H. and Meena, B.L. (2019). Impact of bio-fertilizer on growth, yield and quality of onion (Allium cepa L.) cv. Pusa red. Plant Archives, 19(1): $772-776$.

Kumari, S., Bharat, N.K. and Chauhan, D.S. (2019). Efficacy of PGPR and Trichoderma on growth and yield parameters of bell pepper (Capsicum annuum L.). Journal of Plant Development Science, 11(9):493-499. 
Kumavat, S.D. and Chaudhari, Y.S. (2013). Lycopene and it's role as prostate cancer chemo preventive agent. Int. J. of Research in Pharmacy and Chemistry, 3 (3): 545-551.

Meena, D.C., Maji, S., Meena, J.K., Kumawat, R., Meena, K.R., Kumar, S. and Sodh, K. (2015). Improvement of Growth, Yield and Quality of Tomato (Solanum lycopersicum L.) cv.Azad T6 with Foliar Application of Zinc and Boron. International Journal of Bio-Resource \& Stress Management, 6(5):598-601.

Molla, A.H., Haque, M.M., Haque, M.A. and Ilias, G.N.M. (2012). Trichoderma-enriched biofertilizer enhances production and nutritional quality of tomato (Lycopersicon esculentum Mill.) and minimizes NPK fertilizer use. Agricultural Research, 1 (3) : 265-272.

Nzanza, B., Marais, D. and Soundy, P. (2012). Yield and nutrient content of tomato (Solanum lycopersicum L.) as influenced by Trichoderma harzianum and Glomus mosseae inoculation. Scientia Horticulturae, 14(4) : 55-59.

Prasad, P.S. and Subbarayappa, C.T. (2018). Effect of soil application of zinc on growth and quality of Tomato (Solanum lycopersicon L.) in different zinc fertility soils of eastern dry zone (Zone V) of Karnataka. Journal of Pharmacognosy and Phytochemistry, 7 (4) : 298-302.

Salam, M.A., Siddique, M.A., Rahim, M.A., Rahman, M.A. and Saha, M.G. (2010). Quality of tomato (Lycopersicon esculentum Mill.) as influenced by boron and zinc under different levels of NPK fertilizers. Bangladesh Journal of Agricultural Research, 35(3):475-488.
Samreen, T., Shah, H.U., Ullah, S. and Javid, M. (2017). Zinc effect on growth rate, chlorophyll, protein and mineral contents of hydroponically grown mungbeans plant (Vigna radiata). Arabian Journal of Chemistry, 10:S1802-S1807.

Sathiyamurthy, V.A., Shanmugasundaram, T., Rajasree, V. and Arumugam, T. (2017). Effect of Foliar Application of Micronutrients on Growth, Yield and Economics of Tomato(Lycopersicon esculentum Mill.). Madras Agricultural Journal, 104 (4-6): 188-193.

Shahid, I., Tariq, K. and Mehnaz, S. (2020). Zinc solubilizing fluorescent Pseudomonasas biofertilizer for Tomato (Solanum lycopersicum L.) under controlled conditions.Asian Journal of Plant Science and Research, 10(1): 1-7.

Sharma, A., Patni, B., Shankhdhar, D. and Shankhdhar, S.C. (2013). Zinc-an indispensable micronutrient. Physiology and Molecular Biology of Plants, 19 (1):11-20.

Singh, P. and Sharma, D.P. (2019). Effect of micronutrients and bio inoculants (Trichodermaviride and PGPR) on yield parameters of chilli (Capsicum annum L.). IJCS, 7 (4) : 773 775 .

Ullah, R., Ayub, G., Ilyas, M., Ahmad, M., Umar, M., Mukhtar, S. and Farooq, S. (2015). Growth and yield of tomato (Lycopersicon esculentum L.) as influenced by different levels of zinc and boron as foliar application. AmericanEurasian J. Agric. and Environ. Sci, 15 (12) : 2495-2498. 